\title{
Evaluation of different expression systems for the heterologous expression of pyranose 2-oxidase from Trametes multicolor in E. coli
}

\author{
Oliver Spadiut ${ }^{1,3}$, Gerald Posch ${ }^{1,2,4}$, Roland Ludwig ${ }^{1,2}$, Dietmar Haltrich ${ }^{1}$, Clemens K Peterbauer ${ }^{{ }^{*}}$
}

\begin{abstract}
The heterologous production of the industrially relevant fungal enzyme pyranose 2-oxidase in the prokaryotic host $E$. coli was investigated using 3 different expression systems, i.e. the well-studied T7 RNA polymerase based pET21 ${ }^{+}$, the L-arabinose inducible PBAD and the PCOLD system. Preliminary experiments were done in shaking flasks at $25^{\circ} \mathrm{C}$ and optimized induction conditions to compare the productivity levels of the different expression systems. The pET21 d and the pCOLD system gave $29 \mathrm{U} / \mathrm{L} \cdot \mathrm{h}$ and $14 \mathrm{U} / \mathrm{L} \cdot \mathrm{h}$ of active pyranose 2-oxidase, respectively, whereas the pBAD system only produced $6 \mathrm{U} / \mathrm{L} \cdot \mathrm{h}$. Process conditions for batch fermentations were optimized for the pET21 $\mathrm{d}^{+}$ and the PCOLD systems in order to reduce the formation of inactive inclusion bodies. The highest productivity rate with the pET21 $\mathrm{d}^{+}$expression system in batch fermentations was determined at $25^{\circ} \mathrm{C}$ with $32 \mathrm{U} / L \cdot h$. The pCOLD system showed the highest productivity rate $(19 \mathrm{U} / L \cdot h)$ at $25^{\circ} \mathrm{C}$ and induction from the start of the cultivation. Using the PCOLD system in a fed batch fermentation at $25^{\circ} \mathrm{C}$ with a specific growth rate of $\mu=0.15 \mathrm{~h}^{-1}$ resulted in the highest productivity rate of active pyranose oxidase with $206 \mathrm{U} / \mathrm{L} \cdot \mathrm{h}$.
\end{abstract}

\section{Background}

Enzymatic catalysis provides tremendous opportunities for industry to carry out efficient and economical biocatalytic conversions. Traditional markets include the food and feed industry, but enzymatic processes are increasingly implemented in emerging markets such as fine chemical production and pharmaceutical industries [1]. Cost-efficient high-yield production of the biocatalysts, usually by heterologous expression in bacterial or yeast systems, is critical for the economic viability of such processes. The choice of the production host depends on several properties of the target protein itself. If posttranslational modifications are not required, prokaryotic systems like $E$. coli are most attractive due to high productivity, low cost and easy handling. However, overexpression of recombinant proteins in bacteria can cause problems like the production of insoluble aggregates of misfolded and inactive proteins called inclusion bodies (IB). Inclusion bodies consist of the overproduced polypeptide aggregated with small amounts of foreign

\footnotetext{
* Correspondence: clemens.peterbauer@boku.ac.at

${ }^{1}$ Food Biotechnology Lab, Department of Food Sciences and Technology, BOKU - University of Natural Resources and Applied Life Sciences Vienna,
} Austria

(c) 2010 Spadiut et al; licensee BioMed Central Ltd. This is an Open Access article distributed under the terms of the Creative Commons Attribution License (http://creativecommons.org/licenses/by/2.0), which permits unrestricted use, distribution, and reproduction in any medium, provided the original work is properly cited. proteins and nucleic acids [2]. Strategies for resolving this problem and for optimizing expression levels in E. coli have already been reported [3-7] and include the application of well-characterized expression systems under the control of tightly regulated promoters as well as the application of different expression conditions. In general, reduced cell growth, caused by lowered temperatures or oxygen limitation, promotes the expression of complex heterologous proteins in an active and soluble form and reduces IB formation [8-11]. Overdrive of inducer, on the other hand, results in IB formation and cell damage, whereas limited induction is favorable for native enzyme production [12]. Refolding of IB is widely discussed in literature $[13,14]$, but is not possible for every given protein.

In this study we analyzed different expression systems for the production of recombinant pyranose 2-oxidase (POx; pyranose:oxygen 2-oxidoreductase; glucose 2-oxidase; EC 1.1.3.10) from Trametes multicolor in the prokaryotic host E. coli. POx is a homotetrameric flavoprotein, typically of a molecular mass of $270 \mathrm{kDa}$, with each of the four $68-k D a$ subunits carrying one covalently bound flavin adenine dinucleotide (FAD). It is widespread in wooddegrading basidiomycetes and catalyzes the oxidation of 
different aldopyranoses at $\mathrm{C} 2$ to the corresponding 2-ketoaldoses, producing $\mathrm{H}_{2} \mathrm{O}_{2}$ as a by-product [15-17]. In the past few years, $\mathrm{POx}$ has gained increasing attention for industrial applications, such as the synthesis of carbohydrate derivates and rare sugars [18], analytical applications [19], as well as for applications in enzymatic biofuel cells [20]. Cost-efficient enzyme supply is critical for any such application. The heterologous expression of POx in E. coli has been investigated before [21-23]. However, these studies only dealt with one expression system based on the vector pSE420 (Invitrogen) and improvement of POx expression by medium optimization and oxygen limitation, and enzyme yields remained limited due to IB formation.

It was the goal of this work to investigate different expression systems for POx in E. coli and to optimize the production in a bioreactor to minimize the formation of insoluble IB. Apart from the T7 RNA polymerase based $\mathrm{pET} 21 \mathrm{~d}^{+}[24]$, we investigated the L-arabinose inducible pBAD $[25,26]$ and the pCOLD expression system $[27,28]$.

\section{Methods}

\section{Microorganisms and cultivation}

Escherichia coli BL21 DE3 and E. coli TOP10 cells were used for maintenance and propagation of plasmids and as hosts for expression studies. For propagation, E. coli cells were cultivated in $\mathrm{TB}_{\mathrm{amp}}$-media (yeast extract $24 \mathrm{~g} / \mathrm{L}$; peptone from casein $12 \mathrm{~g} / \mathrm{L}$; glycerol $4 \mathrm{~mL} / \mathrm{L} ; \mathrm{KH}_{2} \mathrm{PO}_{4-}$ buffer $1 \mathrm{M}, \mathrm{pH} 7.5)$ under appropriate selective conditions (ampicillin was added to a final concentration of $0.1 \mathrm{~g} / \mathrm{L})$.

The inoculi for the different fermentations were cultivated in a defined Seed Stage Medium (glycerol $5 \mathrm{~g} / \mathrm{L}$; peptone from casein $5 \mathrm{~g} / \mathrm{L}$; yeast extract $5 \mathrm{~g} / \mathrm{L} ; \mathrm{NaCl} 5$ $\mathrm{g} / \mathrm{L}$; ampicillin $0.1 \mathrm{~g} / \mathrm{L}$ ). For cultivation and expression studies, E. coli cells were grown in a Production Stage Medium in the bioreactors (MPCGly-Medium: glycerol $10 \mathrm{~g} / \mathrm{L}$; peptone from casein $10 \mathrm{~g} / \mathrm{L} ; \mathrm{M} 9-S a l t s 5 \times$ conc. $200 \mathrm{~mL} / \mathrm{L})$. The M9-Salts $5 \times$ conc. solution $\left(\mathrm{Na}_{2} \mathrm{H}\right.$ $\mathrm{PO}_{4} \cdot 2 \mathrm{H}_{2} \mathrm{O} 42.5 \mathrm{~g} / \mathrm{L} ; \mathrm{KH}_{2} \mathrm{PO}_{4} 15.0 \mathrm{~g} / \mathrm{L} ; \mathrm{NaCl} 2.5 \mathrm{~g} / \mathrm{L}$; $\mathrm{NH}_{4} \mathrm{Cl} 5.0 \mathrm{~g} / \mathrm{L}$ ) was prepared and autoclaved separately. After sterilization, the M9-Salts $5 \times$ conc. solution, 10 $\mathrm{mL} \mathrm{MgSO}_{4}[1 \mathrm{M}], 0.5 \mathrm{~mL} \mathrm{CaCl}_{2}[1 \mathrm{M}], 0.1 \mathrm{~mL} / \mathrm{L}$ sterile antifoam and $0.1 \mathrm{~g} / \mathrm{L}$ ampicillin were injected through a sterile filter into the bioreactor.

For fed-batch experiments a chemically defined Synthetic Medium was developed (glycerol $185.6 \mathrm{~g} / \mathrm{L} ;\left(\mathrm{NH}_{4}\right)$ ${ }_{2} \mathrm{SO}_{4} 61.7 \mathrm{~g} / \mathrm{L} ; \mathrm{KH}_{2} \mathrm{PO}_{4} 5 \mathrm{~g} / \mathrm{L} ; \mathrm{Na}_{2} \mathrm{HPO}_{4} \cdot 2 \mathrm{H}_{2} \mathrm{O} 11.5 \mathrm{~g} / \mathrm{L}$; $\mathrm{MgSO}_{4} \cdot 7 \mathrm{H}_{2} \mathrm{O}[1 \mathrm{M}] 19 \mathrm{~mL} / \mathrm{L} ; \mathrm{CaCl}_{2} \cdot 6 \mathrm{H}_{2} \mathrm{O}\left[\begin{array}{ll}1 & \mathrm{M}\end{array}\right]$ $10.5 \mathrm{~mL} / \mathrm{L}$; lactose monohydrate $5.25 \mathrm{~g} / \mathrm{L}$; trace element solution $10 \mathrm{~mL} / \mathrm{L}$; ampicillin $0.1 \mathrm{~g} / \mathrm{L}$ ). The trace element solution $\left(\mathrm{FeCl}_{3}\right.$ anhydrous $4.00 \mathrm{~g} / \mathrm{L} ; \mathrm{MnCl}_{2} \cdot 4 \mathrm{H}_{2} \mathrm{O} 2.35$ $\mathrm{g} / \mathrm{L} ; \quad \mathrm{ZnSO}_{4} \cdot 7 \mathrm{H}_{2} \mathrm{O} \quad 1.60 \mathrm{~g} / \mathrm{L} ; \mathrm{H}_{3} \mathrm{BO}_{3} \quad 0.50 \mathrm{~g} / \mathrm{L}$; $\mathrm{CoCl}_{2} \cdot 6 \mathrm{H}_{2} \mathrm{O} 0.40 \mathrm{~g} / \mathrm{L} ;\left(\mathrm{NH}_{4}\right)_{6} \mathrm{Mo}_{7} \mathrm{O}_{24} \cdot 4 \mathrm{H}_{2} \mathrm{O} 0.40 \mathrm{~g} / \mathrm{L}$;
$\mathrm{CuCl}_{2}$ anhydrous $0.25 \mathrm{~g} / \mathrm{L}$ ) was prepared separately, filter sterilized and added to the sterile medium. The chemicals used were of the purest grade available and purchased from Sigma (Vienna, Austria) and Roth (Karlsruhe, Germany).

Construction of the expression vectors $\mathrm{pET} 21 \mathrm{~d}^{+} / \mathrm{POx}$, pBAD His A/POx and pCOLDIII/POx

Nucleotides, buffers and enzymes were purchased from Fermentas (St. Leon-Rot, Germany).

The construction of the $\mathrm{pET} 21 \mathrm{~d}^{+} / \mathrm{POx}$ vector (pHL2), which contains the His-tagged pyranose 2-oxidase gene from Trametes multicolor under the control of the $\mathrm{T} 7$ promoter, is described elsewhere [29].

To obtain a tightly regulated expression system we used the $\mathrm{pBAD} /$ His A vector (Invitrogen; Carlsbad, CA, U.S.A.) using the L-arabinose inducible araBAD promoter, which displays only very low transcription levels in the absence of arabinose. The POx-encoding gene from pHL2 was amplified using the primers BAD_PstI_fwd (5'-aagaaggagctgcagcatggctacc-3') and BAD_EcoRI_rev (5'-gctcgagtggaattcctcactgagcc-3'). After double digestion with PstI and EcoRI, the POx gene fragment was ligated into the PstI/EcoRI digested pBAD His A vector at $16^{\circ} \mathrm{C}$ over night.

The cold-shock expression vector III (pCOLD III; Takara Bio Inc., Japan) contains the promoter of the cold-shock gene $\operatorname{csp} A$. The POx-encoding gene from pHL2 was amplified using the primers COLD_fwd (5'-aggagatatcatatggctaccagctcg-3') and COLD_rev (5'-gttagcagcctgcagtcagtggtg- $\left.3^{\prime}\right)$. Both the PCR fragment and the pCOLD III plasmid where double-digested with NdeI and PstI and ligated at $16^{\circ} \mathrm{C}$ over night.

Correct insertion of the POx-encoding genes and the absence of mutations were checked by DNA sequencing, and verified plasmids were transformed into E. coli BL21 DE3 (pET21 $\mathrm{d}^{+}$- and pCOLD-derivatives) and E. coli TOP10 (pBAD-derivative).

\section{Shake-flask cultivations}

In order to compare the amount of soluble, active POx of the 3 different expression systems, preliminary experiments in baffled shake-flasks were carried out at $25^{\circ} \mathrm{C}$. According to Kotik et al. [22] an induction with $0.5 \%$ lactose $(\mathrm{w} / \mathrm{v})$ for the $\mathrm{pET} 21 \mathrm{~d}^{+}$system was used. For the pBAD system the concentration of the inducer L-arabinose was varied from 0.001 to $1 \%(\mathrm{w} / \mathrm{v})$ according to the manufacturer's recommendations. The comparative study at $25^{\circ} \mathrm{C}$ was then performed by inducing the cultures with an optimal concentration of $0.1 \% \mathrm{~L}$-arabinose. Small-scale tests showed no difference in expression between induction with either IPTG $(0.1,0.5$ and $1.0 \mathrm{mM})$ or lactose $(0.5 \% \mathrm{w} / \mathrm{v})$ using the pCOLD system, therefore the cheaper lactose was used for induction. All cultures were induced at an $\mathrm{OD}_{600} \sim 0.5$ and cultivated at 
$25^{\circ} \mathrm{C}$ for $20 \mathrm{~h}$. After centrifugation, cells were lysed using a French Press and POx activity was analyzed by the chromogenic ABTS assay [30].

\section{Preparation of the working cell bank and preculture}

A single colony of transformed $E$. coli cells was used as inoculum for $50 \mathrm{~mL} \mathrm{~TB}_{\mathrm{amp}}$ in baffled flasks at $37^{\circ} \mathrm{C}$ and was grown to an optical density $\mathrm{OD}_{600}$ of $\sim 1.0$. To obtain the working cell bank, $500 \mu \mathrm{L}$ of this cell suspension were mixed with $250 \mu \mathrm{L}$ sterile $75 \%$ glycerol, frozen in liquid nitrogen and stored at $-70^{\circ} \mathrm{C}$.

As a preculture, Erlenmeyer flasks containing $250 \mathrm{~mL}$ sterile Seed Stage Medium were inoculated with $250 \mu \mathrm{L}$ of working cell bench suspension and incubated at $37^{\circ} \mathrm{C}$ and $140 \mathrm{rpm}$. At an $\mathrm{OD}_{600}$ of $\sim 0.5$, this preculture $(5 \%$ $(\mathrm{v} / \mathrm{v})$ of the total culture volume) was transferred into the bioreactor.

\section{Bioreactor studies}

Batch cultivations were done in $42 \mathrm{~L}$ computer-controlled stirred tank reactors (Applikon, Schiedam, the Netherlands), with a working volume of $30 \mathrm{~L}$. Culture $\mathrm{pH}$ was maintained at $\mathrm{pH} 7.0$ by automatic addition of sterile $\mathrm{NaOH}[4 \mathrm{M}]$ and the dissolved oxygen concentration $\left(\mathrm{DO}_{2}\right)$ was set to $30 \%$. The parameters were controlled using a Bio Controller ADI 1030 digital controller (Applikon) and online-monitored by a computer data logger (BioExpert NT, Applikon). $\mathrm{DO}_{2}$ levels were maintained by supplying filtered air automatically $(0-15 \mathrm{~L} / \mathrm{min})$ and adjusting the stirrer velocity. Temperature, inducer concentration and time of induction were varied to optimize protein expression.

Fed-batch experiments were performed in a $7 \mathrm{~L}$ stirred tank reactor (MBR Bio Reactor AG, Wetzikon, Switzerland). Online process parameters were controlled by an IMCS-2000 digital control unit (PCS AG, Wetzikon, Switzerland). One hundred and twenty five $\mathrm{mL}$ of preculture were used to inoculate an initial batch phase volume of $2.5 \mathrm{~L}$. Fed-batch experiments were operated at $25^{\circ} \mathrm{C}$ and the medium was always supplemented with lactose $0.5 \%(\mathrm{w} / \mathrm{v})$ for induction of POx expression from the beginning of cultivation. Following glycerol depletion, which was indicated by a rapid increase of $\mathrm{DO}_{2}$, the fed-batch phase was started. Carbon-limited exponential feeding was carried out according to a predetermined model (formula for glycerol feed: $y=11.25$ * $\mathrm{e}^{0.15 \mathrm{x}}, \mathrm{R}^{2}=1 ; \mathrm{x}$ is the biomass concentration in $\mathrm{g} / \mathrm{L}$ ) using a P-1 peristaltic pump (Pharmacia Biotech, Uppsala, Sweden). The feed pump was operated manually and feed flow rates were adjusted every hour to maintain exponential feeding rates. High levels of glycerol had to be avoided in order to maintain a desired specific growth rate of $\mu=0.15 \mathrm{~h}^{-1}$.

\section{Off-line analysis of parameters}

Samples were taken in appropriate time intervals during fermentations and analyzed for optical density at 600 $\mathrm{nm}\left(\mathrm{OD}_{600}\right)$, dry cell weight (DCW) and concentration of the substrate glycerol and the inducer lactose. Likewise, POx activity and the total intracellular protein concentration were determined to evaluate the performance of the expression system. To evaluate the applied process conditions, the factor $\mathrm{Yx} / \mathrm{s}$ was determined. $\mathrm{Yx} / \mathrm{s}$ stands for the amount of biomass [g] which was produced per $g$ of substrate.

Optical density was measured in duplicates. DCW $[\mathrm{g} / \mathrm{L}]$ was determined by centrifuging $20 \mathrm{~mL}$ of cell suspension in a previously dried and pre-weighed centrifuge tube at $4000 \mathrm{rpm}$ for $15 \mathrm{~min}$. Lactose and glycerol concentrations in the supernatant were determined by using test kits (Hoffmann-La Roche Ltd, Basel, Switzerland; Megazyme International Ireland Ltd., Wicklow, Ireland) following the manufacturer's protocols, the cells were washed twice with $20 \mathrm{~mL} \mathrm{H}_{2} \mathrm{O}$ dist. and $\mathrm{DCW}$ was determined after drying the wet pellet at $60^{\circ} \mathrm{C}$ to a constant weight.

POx activity was measured with the standard chromogenic ABTS [2,2'-azinobis(3-ethylbenzthiazolinesulfonic acid)] assay [30] from the sample crude extract after cell disruption using a French press. A sample of diluted enzyme $(10 \mu \mathrm{l})$ was added to $980 \mu \mathrm{l}$ assay buffer containing horseradish peroxidase (142 U), ABTS (14.7 mg) and $\mathrm{KH}_{2} \mathrm{PO}_{4}$-buffer $(50 \mathrm{mM}, \mathrm{pH}$ 6.5). The reaction was started by addition of D-glucose $(20 \mathrm{mM})$. The absorbance change at $420 \mathrm{~nm}$ was recorded at $30^{\circ} \mathrm{C}$ for $180 \mathrm{sec}$. The chromophore $\varepsilon_{420}$ used was $42.3 \mathrm{mM}^{-1} \cdot \mathrm{cm}^{-1}$. One Unit of POx activity was defined as the amount of enzyme necessary for the oxidation of $2 \mu \mathrm{mol}$ of ABTS per min (which equals the consumption of $1 \mu \mathrm{mol}$ of $\mathrm{O}_{2}$ ) under the assay conditions. Kinetic constants were calculated by non-linear least-square regression, fitting the data to the HenriMichaelis-Menten equation. Protein concentrations were determined at $595 \mathrm{~nm}$ by the Bradford assay [31] using the BioRad Protein Assay Kit (BioRad; Vienna, Austria) with bovine serum albumin (BSA) used in concentrations of $0.1-1.0 \mathrm{mg} / \mathrm{mL}$ for the standard calibration curve.

\section{Electrophoresis}

After homogenization of the samples cell debris including IB was harvested by centrifugation $\left(13200 \mathrm{rpm}, 4^{\circ} \mathrm{C}\right.$, $20 \mathrm{~min})$. An aliquot of this pellet $(100 \mathrm{mg})$ was washed 2 times with $\mathrm{H}_{2} \mathrm{O}$ dist., resuspended in $\mathrm{H}_{2} \mathrm{O}$ dist. and analyzed for the presence of IB by SDS-PAGE, as described by Laemmli [32]. To analyze the expression of soluble POx, $50 \mu \mathrm{l}$ of crude extract were mixed with $50 \mu \mathrm{l}$ Laemmli buffer, heated at $95^{\circ} \mathrm{C}$ for 5 min and analyzed. SDS-PAGE was performed using a $5 \%$ stacking gel and a $10 \%$ separating gel run in a PerfectBlue vertical 
electrophoresis system (Peqlab; Erlangen, Germany). Samples were diluted to $\sim 1 \mathrm{mg}$ of protein per millilitre and aliquots of $5 \mu \mathrm{l}$ were loaded per lane. The molecular weight standard used was the Precision Plus Protein Dual Color (Biorad), and the gels were stained with Coomassie blue.

\section{Results and discussion}

\section{Preliminary expression experiments at $25^{\circ} \mathrm{C}$}

In order to compare the amount of soluble, active POx in the 3 different expression systems, preliminary experiments in baffled shake-flasks at $25^{\circ} \mathrm{C}$ were carried out. The pET21d ${ }^{+}$and the pCOLD system were induced by addition of $0.5 \%$ lactose $(\mathrm{w} / \mathrm{v})$; for the pBAD system, an L-arabinose concentration of $1 \mathrm{~g} / \mathrm{L}(0.1 \% \mathrm{w} / \mathrm{v}$, Fig. 1$)$ resulted in the highest expression of active POx. Consequently, this concentration was used for further comparative studies.

In these experiments at $25^{\circ} \mathrm{C}$ and optimal induction, the pET21 $\mathrm{d}^{+}$system showed the highest productivity rate of $29 \mathrm{U} / \mathrm{L} \cdot \mathrm{h}$ active, recombinant POx. With the pCOLD system, 14 Units active POx were produced per liter and hour. Possible effects of the temperature resulting in only half the yield compared to the $\mathrm{pET} 21 \mathrm{~d}^{+}$system were further investigated in batch fermentation studies. The tightly regulated $\mathrm{L}$-arabinose inducible pBAD system showed a productivity rate of only $6 \mathrm{U} /$ L.h, approximately $20 \%$ of the pET $21 \mathrm{~d}^{+}$system. Crude extracts, which were obtained by lysis of $1 \mathrm{~g}$ of wet biomass, were also analyzed for their content of expressed POx by SDS-PAGE (Fig. 2). The pBAD expression system was not competitive compared with $\mathrm{pET} 21 \mathrm{~d}^{+}$and pCOLD, and was not investigated further.

\section{Expression of POx using the pET21 $\mathrm{d}^{+}$expression system} The expression vector $\mathrm{pET} 21 \mathrm{~d}^{+}$and other derivatives based on the T7 RNA polymerase promoter are widely

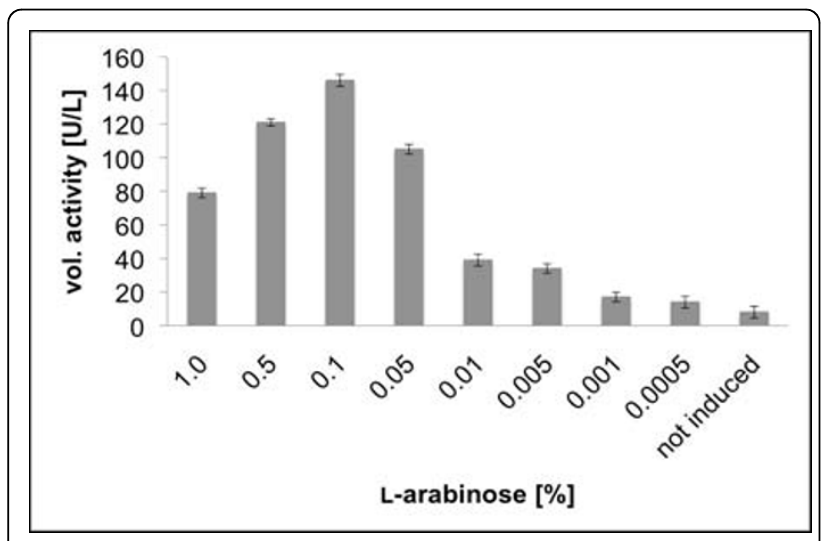

Figure 1 Volumetric activity [U/L] of POx obtained in cultivations in baffled shaking flasks to analyze the optimal concentration of L-arabinose for induction of the PBAD HisA/ POx expression system at $25^{\circ} \mathrm{C}$.

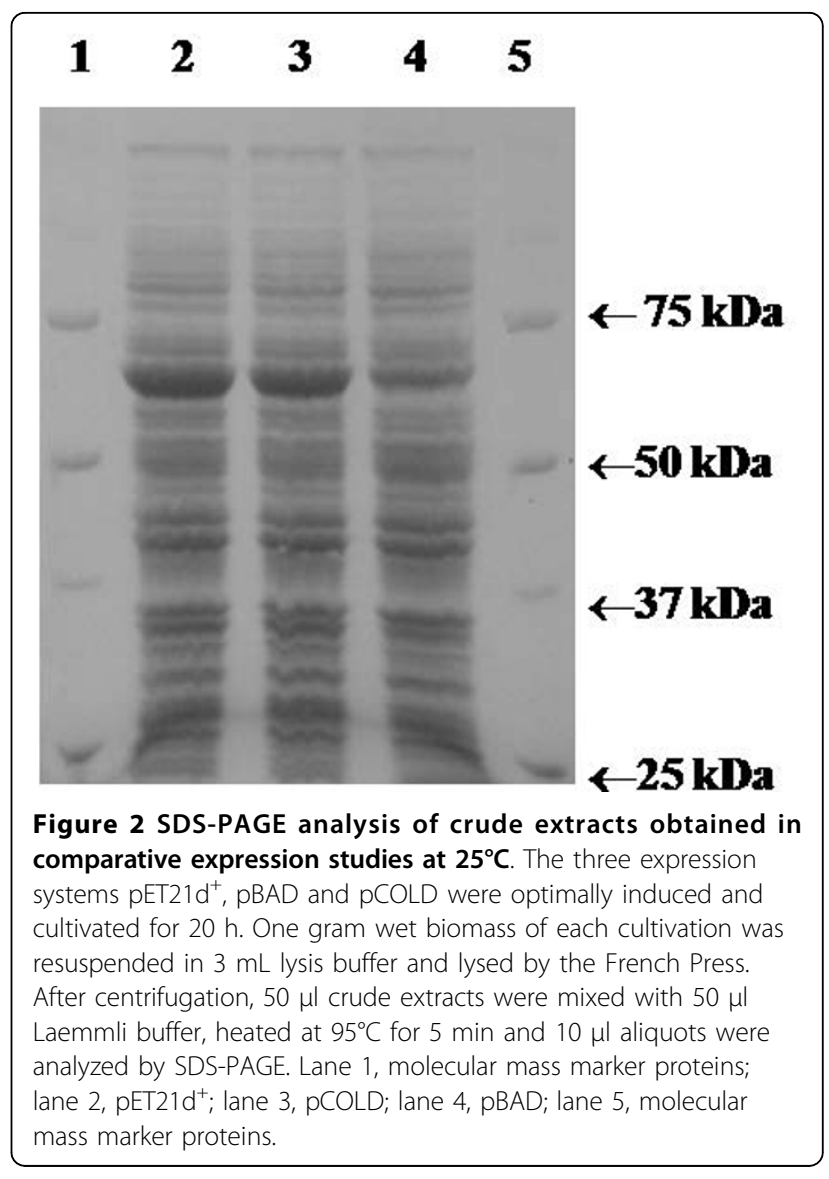

used for the heterologous expression of proteins in bacteria. In previous reports, POx was shown to be highly susceptible to IB formation using the similar expression system pSE420 under the control of the trc promoter in E. coli $[22,23]$. Kotik et al. used 3 different temperatures $\left(37^{\circ} \mathrm{C}, 25^{\circ} \mathrm{C}\right.$ and $\left.22^{\circ} \mathrm{C}\right)$ and oxygen limitation at $25^{\circ} \mathrm{C}$ to reduce IB formation, but the results were not satisfying. In the latter work, limited oxygen rates led to increased specific activity of POx, but the reduced growth rate $\mu_{\max }=0.08 \mathrm{~h}^{-1}$ resulted in very long cultivation times. Additionally, complete consumption of lactose may have resulted in a non-permanent induction of protein expression, which makes the data for the fed-batch experiments difficult to interpret.

Therefore, process conditions had to be optimized to minimize the formation of IB. Table 1 summarizes fermentation experiments to analyze the effect of temperature and time of induction on the expression of active POx. In all fermentations protein expression was induced by $0.5 \%$ lactose $(\mathrm{w} / \mathrm{v})$, which allowed continuous induction throughout the process.

Fermentation 1 at $37^{\circ} \mathrm{C}$ was divided into a short lag phase and a very short exponential phase. Glycerol was depleted after 23 hours. Growth rate was very high 
Table 1 Important parameters and results of 6 different batch fermentations using the $\mathrm{PET} 21 \mathrm{~d}^{+} / \mathrm{POx}$ expression system.

\begin{tabular}{ccccccc}
\hline fermentation & $\mathbf{1}$ & $\mathbf{2}$ & $\mathbf{3}$ & $\mathbf{4}$ & $\mathbf{5}$ & $\mathbf{6}$ \\
\hline time of induction $[\mathrm{h}]$ & 0 & 0 & 0 & $6\left(\mathrm{OD}_{600}=0.7\right)$ & 0 & 0 \\
temp. $\left[^{\circ} \mathrm{C}\right]$ & 37 & 30 & 25 & 25 & 22 & 18 \\
$\mathrm{DCW}[\mathrm{g} / \mathrm{L}]$ & 4.5 & 4.6 & 4.6 & 3.2 & 5.7 & 4.1 \\
$\mathrm{Yx} / \mathrm{s}[\mathrm{g} / \mathrm{g}]$ & 0.46 & 0.46 & 0.47 & 0.33 & 0.56 & 0.41 \\
$\mu_{\max }\left[\mathrm{h}^{-1}\right]$ & 1.15 & 0.88 & 0.48 & 1.25 & 0.23 & 0.20 \\
vol. activity $[\mathrm{U} / \mathrm{L}]$ & 1 & 45 & 916 & 425 & 1155 & 1300 \\
process time $[\mathrm{h}]$ & 25 & 25 & 26 & 22 & 40 & 50 \\
productivity $[\mathrm{U} / \mathrm{L} \cdot \mathrm{h}]$ & 0 & 2 & 32 & 18.5 & 28 & 26 \\
space time yield $[\mathrm{mg} / \mathrm{L} \cdot \mathrm{h}]$ & 0 & 0.3 & 4.0 & 2.3 & 3.5 & 3.3 \\
\hline
\end{tabular}

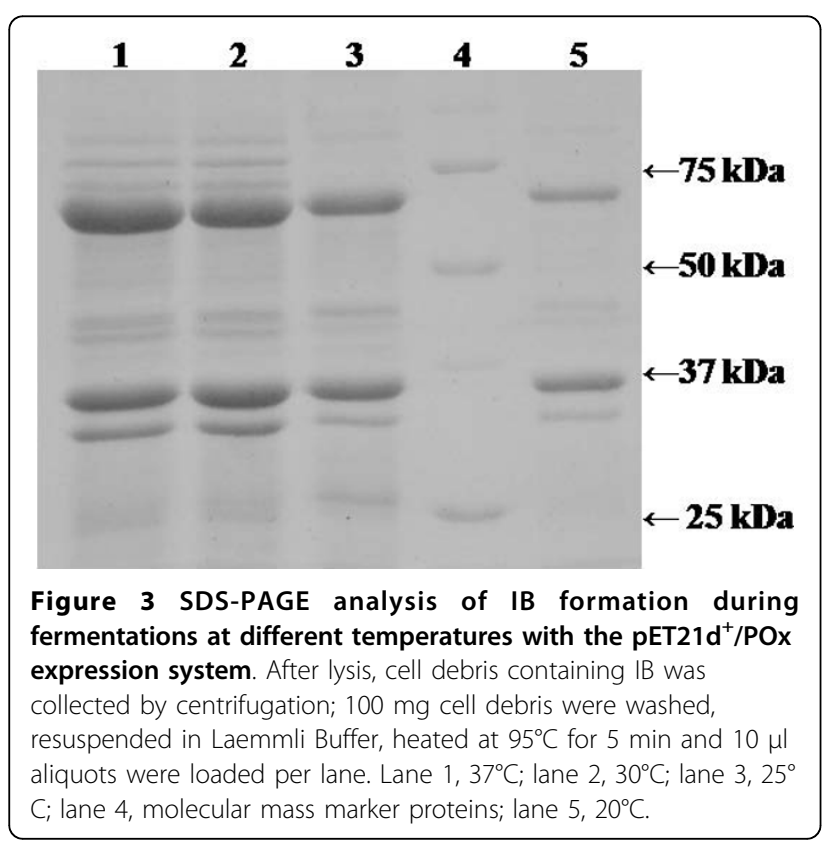

$\left(\mu_{\max }=1.15 \mathrm{~h}^{-1}\right)$, but no active POx could be detected, only IB (Fig. 3). Fermentation 2 at $30^{\circ} \mathrm{C}$ was characterized by a short lag phase but a longer exponential phase compared to fermentation 1. Growth rate was still high $\left(\mu_{\max }=0.88 \mathrm{~h}^{-1}\right)$, but glycerol was not consumed quantitatively. IB formation was still high (Fig. 3), but active POx could be detected, demonstrating the pronounced effect of temperature on IB formation. Two further fermentations under these conditions were performed with lower inducer concentrations $(0.05 \%$ and $0.005 \%$ lactose), but no effect on the expression level of active POx could be detected (data not shown).

In order to further optimize the expression of active, recombinant POx in $E$. coli, additional fermentations at lower temperatures were performed with the same, defined inducer concentration of $0.5 \%$ lactose. Fermentations 3 and 4 were performed at $25^{\circ} \mathrm{C}$ with different induction times (Table 1). Glycerol depletion occurred after 26 and 22 hours, respectively. Induction at an $\mathrm{OD}_{600}$ of $\sim 0.7$ resulted in a much shorter exponential growth phase and a reduced productivity of less than half the amount of soluble, active POx. Production of active enzyme was apparently growth associated and directly proportional to the increase of $\mathrm{OD}_{600}$ (Fig. 4). Obviously, POx production did not cause a metabolic burden on E. coli, the achieved DCW and Yx/s were even higher in Fermentation 3 than in Fermentation 4. Therefore, as described previously also for other recombinant proteins [33], an early induction was possible and resulted in an increased amount of produced recombinant POx. Consequently, induction was started at the beginning of the cultivation in further experiments.

Fermentations 5 and 6 were done at $22^{\circ} \mathrm{C}$ and $18^{\circ} \mathrm{C}$. The lower the temperature, the longer were the lag and the exponential growth phase. After 50 hours of process time still half of the substrate glycerol was left in fermentation 6, and the yield of soluble, active POx was increased up to $1300 \mathrm{U} / \mathrm{L}$. Reduced temperature improved production of native enzyme and reduced IB formation significantly, but process times increased dramatically.

To determine an influence of carbon source limitation on the expression rate of active protein, a series of experiments with limited feed rates (linear and exponential) of glycerol were done. At $30^{\circ} \mathrm{C}$ a linear feed of $0.1 \mathrm{~g}$ glycerol/L.h resulted in a high growth rate of $\mu_{\max }=$ $0.80 \mathrm{~h}^{-1}$ and formation of IB but no active POx. A glycerol feed, which increased according to the $\mathrm{OD}_{600}$ at $25^{\circ} \mathrm{C}$, resulted in a growth rate of $0.47 \mathrm{~h}^{-1}$. Maximum volumetric activity was $834 \mathrm{U} / \mathrm{L}$, due to the lower temperature (data not shown). The more complex fed-batch systems proved again the huge effect of the process temperature on the formation of active POx. By comparing $\mu_{\text {max }}$ and the achieved volumetric activity between the batch and fed-batch systems (see above and Table 1), it became obvious that carbon source limitation was not a successful strategy to minimize the formation of IB.

Summarizing, the temperature of growth was the determining factor for the formation of active POx in E. coli (Fig. 5). At growth rates exceeding $0.25 \mathrm{~h}^{-1}$, volumetric activity yield decreased by at least $20 \%$ due to IB formation. Growth rates in the range of $0.02-0.20 \mathrm{~h}^{-1}$ were favourable for the production of active POx. A sufficient amount of the inducer lactose must be provided during the whole process to guarantee permanent expression. In agreement with previous studies [22] a process temperature of $25^{\circ} \mathrm{C}$ turned out to be optimal for the large scale production of recombinant, active POx using this expression system in terms of both productivity $[\mathrm{U} / \mathrm{L} \cdot \mathrm{h}]$ and process time (Fig. 4). A cultivation temperature of $25^{\circ} \mathrm{C}$ and induction with $0.5 \%(\mathrm{w} / \mathrm{v})$ lactose from the beginning of cultivation resulted in a 


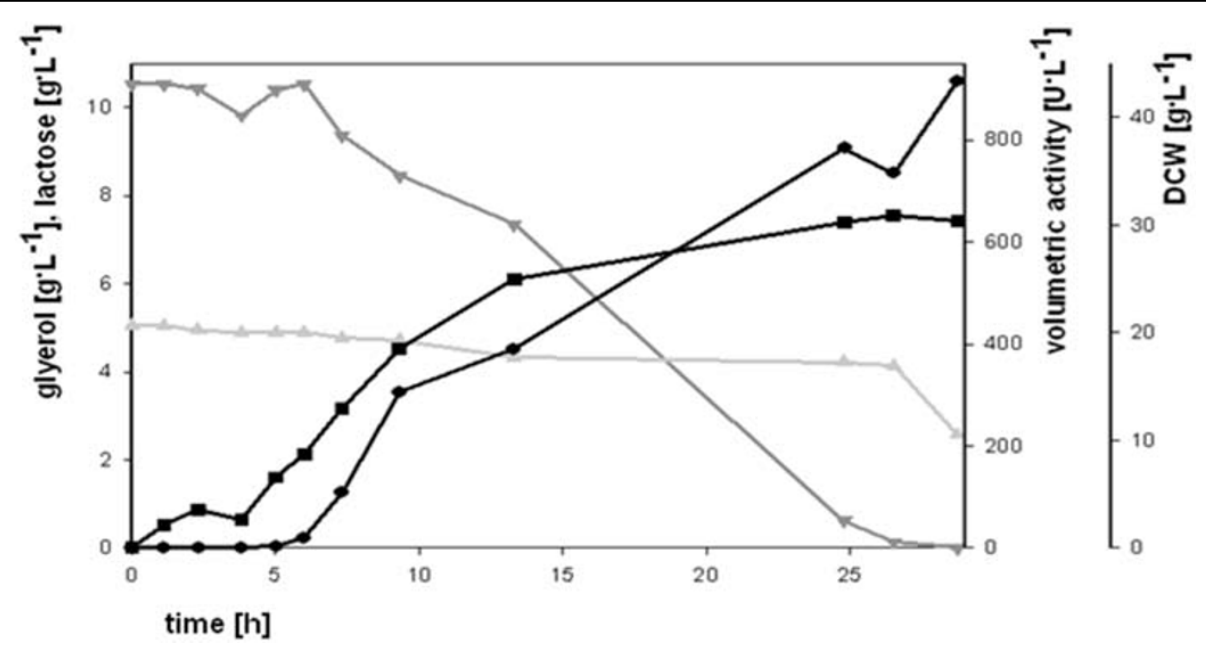

Figure 4 Batch fermentation at $25^{\circ} \mathrm{C}$ and an induction with $0.5 \%$ lactose from the very beginning using the pET21 $\mathrm{d}^{+} / \mathrm{POx}$ expression system. (dark grey triangle), glycerol; (light grey triangle), lactose; (Black square), dry cell weight; (Black circle), volumetric activity of POx.

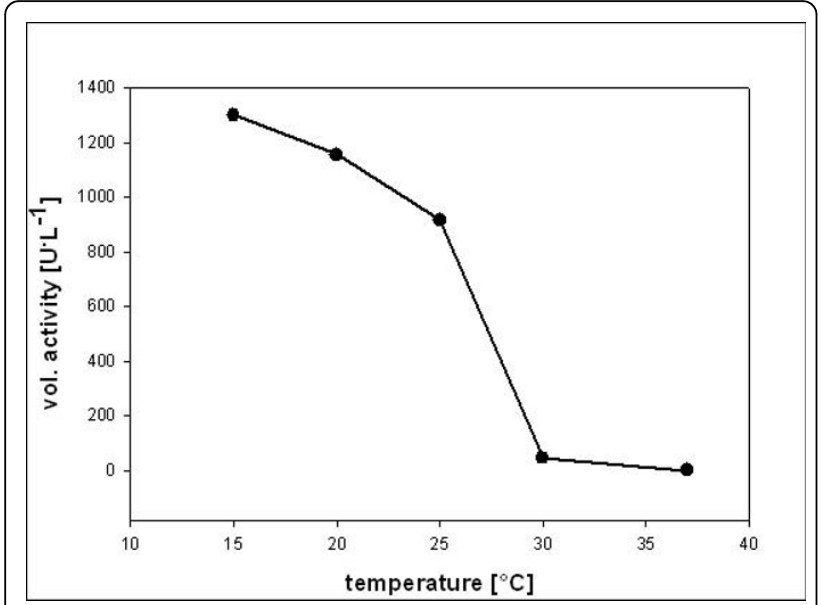

Figure 5 Influence of the growth temperature during batch fermentations on the expression of active, recombinant POx in E. coli.

growth rate of $\mu=0.48 \mathrm{~h}^{-1}$ and a productivity rate of 32 $\mathrm{U} / \mathrm{L} \cdot \mathrm{h}$ active POx. This result is quite different to the data achieved by Kotik et al. [22], who got a productivity rate of $140 \mathrm{U} / \mathrm{L} \cdot \mathrm{h}$ active POx cultivated in batches at $25^{\circ}$ $\mathrm{C}$ and an induction with $0.3 \%(\mathrm{w} / \mathrm{v})$ lactose. This could result from the different expression vector providing the trc promoter, used by Kotik et al. The trc promoter, which is a hybrid of the lac and the trp promoter, is known to be a weaker promoter than the strong T7 promoter, resulting in a reduced production of recombinant protein. Thus, this promoter system gives the E. coli folding machinery more time to successfully process recombinant proteins, instead of producing inactive IB. For the $\mathrm{T} 7$ promoter system instead, even at $25^{\circ} \mathrm{C}$, the large amounts of POx overwhelm the folding machinery of E. coli, resulting in much higher IB formation. A detailed comparative study of these two promoter systems, which has previously shown this result, can be found elsewhere [34].

\section{Expression of POx using the pCOLD expression system}

The expression vector pCOLD III drives protein expression from the promoter of the cold-shock gene $\operatorname{csp} A$. Downstream of the $\operatorname{csp} A$ promoter, a lac operator is inserted so that the expression is controlled by two factors: presence of the inducer IPTG (or lactose) and by cold-shock (see manufacturer's protocol). Lactose concentrations of $5 \mathrm{~g} / \mathrm{L}(0.5 \%)$ were found to be sufficient (data not shown). Bacteria were allowed to grow uninduced at $37^{\circ} \mathrm{C}$ up to certain, different levels of $\mathrm{OD}_{600}\left(\mathrm{OD}_{600}=0.5\right.$ or 2.5 , respectively) before culture broths were cooled down to the final process temperatures of 25,20 and $15^{\circ}$ $\mathrm{C}$, respectively. Addition of the inducer lactose was done simultaneously with temperature downshift. The different conditions and amounts of soluble, active POx are summarized in Table 2. In fermentation 1, POx expression was strictly growth associated and only observed during exponential growth. In total, $330 \mathrm{U} / \mathrm{L}$ of active and soluble enzyme were produced. The maximal growth rate after chilling the culture broth to $25^{\circ} \mathrm{C}$ was determined at $0.23 \mathrm{~h}^{-1}$, which is half the value compared to the pET21d + expression system under equal conditions. Glycerol depletion $26 \mathrm{~h}$ after inoculation resulted in an irreversible stop of POx production. Process time was kept considerably short. In fermentation 2 cells were grown to a higher optical density prior to induction, which did not result in higher yields of active POx. The amount of active POx was $190 \mathrm{U} / \mathrm{L}$, only $40 \%$ of the yield in the first 
Table 2 Growth parameters and results of batch fermentations at different temperatures using the pCOLD III/POx expression system.

\begin{tabular}{ccccccc}
\hline fermentation & $\mathbf{1}$ & $\mathbf{2}$ & $\mathbf{3}$ & $\mathbf{4}$ & $\mathbf{5}$ & $\mathbf{6}$ \\
\hline $\mathrm{OD}_{600}$ at induction & 0.5 & 2.5 & 0.5 & 2.5 & 0.5 & 2.5 \\
temp. $\left[{ }^{\circ} \mathrm{C}\right]$ & 25 & 25 & 20 & 20 & 15 & 15 \\
$\mathrm{DCW}[\mathrm{g} / \mathrm{L}]$ & 4.9 & 5.0 & 4.8 & 4.6 & 4.4 & 4.6 \\
$\mathrm{Yx} / \mathrm{s}[\mathrm{g} / \mathrm{g}]$ & 0.47 & 0.49 & 0.46 & 0.47 & 0.43 & 0.45 \\
$\mu_{\max }\left[\mathrm{h}^{-1}\right]$ & 0.23 & 0.22 & 0.11 & 0.11 & 0.06 & 0.05 \\
vol. activity $[\mathrm{U} / \mathrm{L}]$ & 330 & 190 & 360 & 110 & 580 & 220 \\
process time $[\mathrm{h}]$ & 17 & 13 & 31 & 15 & 49 & 28 \\
productivity $[\mathrm{U} / \mathrm{L} \cdot \mathrm{h}]$ & 19 & 15 & 12 & 7 & 12 & 8 \\
space time yield $[\mathrm{mg} / \mathrm{L} \cdot \mathrm{h}]$ & 2.4 & 1.9 & 1.5 & 0.9 & 1.5 & 1 \\
\hline
\end{tabular}

Protein expression was induced by providing $5 \mathrm{~g} / \mathrm{L}(0.5 \% \mathrm{w} / \mathrm{v})$ lactose at different times.

experiment. Again, expression of POx turned out to be strictly growth associated and therefore stopped upon glycerol depletion (13 $\mathrm{h}$ in this experiment). Apparently, the time of induction had a decisive influence on the performance of this expression system; only when exponentially growing cell cultures were induced, active POx was expressed.

Fermentations 3 and 4 were performed at $20^{\circ} \mathrm{C}$. Selecting $20^{\circ} \mathrm{C}$ as the final downshift temperature did not result in significantly higher expression rates of POx from pCOLD. The specific growth rate $\mu_{\max }$ was remarkably reduced relative to fermentations run at $25^{\circ} \mathrm{C}$, which led to a doubled process time. Fermentation 4 confirmed that the point of induction dramatically affected product yield. Peak POx activity was determined with only $110 \mathrm{U} / \mathrm{L}$, which was less than $60 \%$ compared to fermentation 2. This outcome supported the assumption that POx was only produced by actively growing biomass. Using the pCOLD expression system and growing cells to elevated densities before induction resulted in reduced process times but strongly counteracted product formation. Therefore it seems rational to initiate POx expression early in the process at low cell densities to maximize enzyme production even though this will extend process times.

Fermentation 5 and 6 were performed at $15^{\circ} \mathrm{C}$ resulting in significantly higher yields of active POx. Compared to fermentation 1, in fermentation 5 the amount of active and correctly folded enzyme was increased by $75 \%$, resulting in a final activity of $580 \mathrm{U} / \mathrm{L}$. As shown by SDS-PAGE (Fig. 6), the amount of formed IB decreased significantly at lower temperatures. However, prolonged duration of the process poses a counterbalance to the increase in activity.

Summarizing, it can be said that performing fermentations at low temperatures is a valuable strategy to maximize enzyme production from this promoter system,

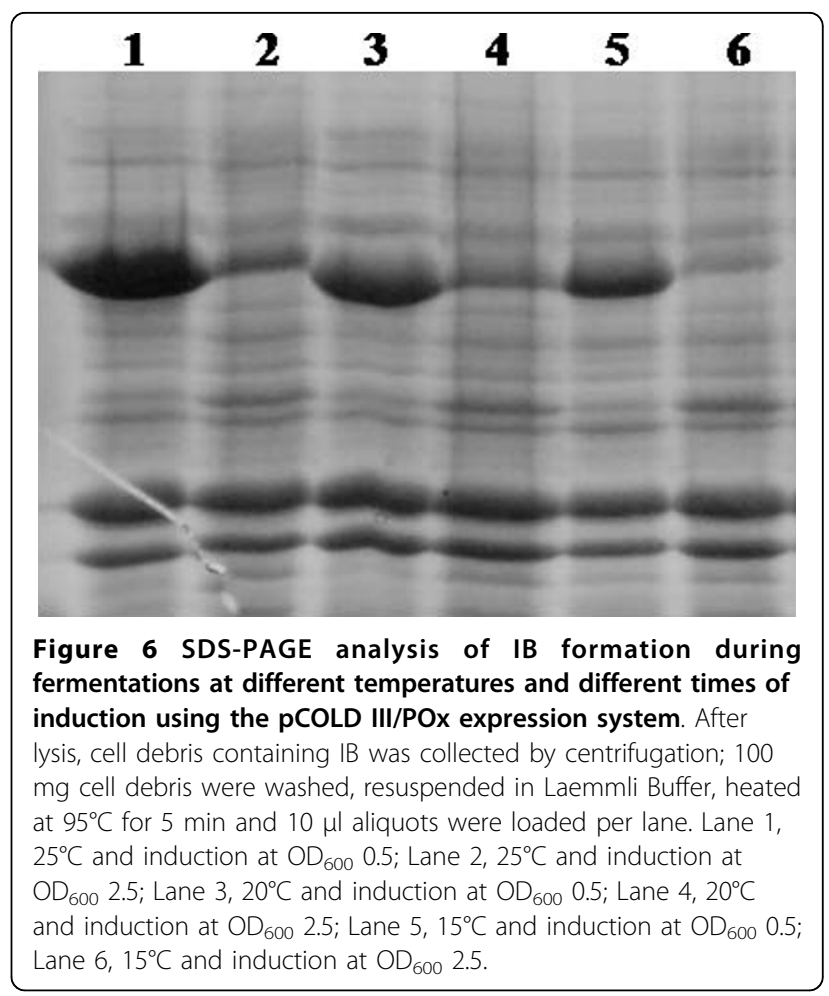

although it has to be carefully estimated whether increased product formation compensates for an extended process time.

\section{Fed-batch fermentation using the pCOLD III/POx expression system}

When the pCOLD expression system was used in batch fermentations, recombinant $\mathrm{POx}$ was only produced by exponentially growing cells. Therefore, achieving high cell densities by applying a fed-batch strategy seemed to be reasonable for maximizing the enzyme yield. The bioreactor was operated at a constant temperature of $25^{\circ} \mathrm{C}$ throughout the process and the medium was supplemented with lactose for induction from the start. We

Table 3 Important parameters for the fed-batch fermentation of pCOLD III/POx at $25^{\circ} \mathrm{C}$.

\begin{tabular}{ccc}
\hline & Batch phase & fed-batch phase \\
\hline $\mathrm{DCW}$ & 5.7 & 28.9 \\
$\mathrm{Yx} / \mathrm{s}$ & 0.55 & 0.47 \\
$\mu_{\max }\left[\mathrm{h}^{-1}\right]$ & 0.24 & 0.15 \\
vol. activity $[\mathrm{U} / \mathrm{L}]$ & 440 & 3300 \\
process time $[\mathrm{h}]$ & 20 & 16 \\
productivity $[\mathrm{U} / \mathrm{L} \cdot \mathrm{h}]$ & 22 & 206 \\
space time yield $[\mathrm{mg} / \mathrm{L} \cdot \mathrm{h}]$ & 2.8 & 25.8
\end{tabular}

Protein expression was induced by addition of lactose $(0.5 \% \mathrm{w} / \mathrm{v})$ from the start of the cultivation. 

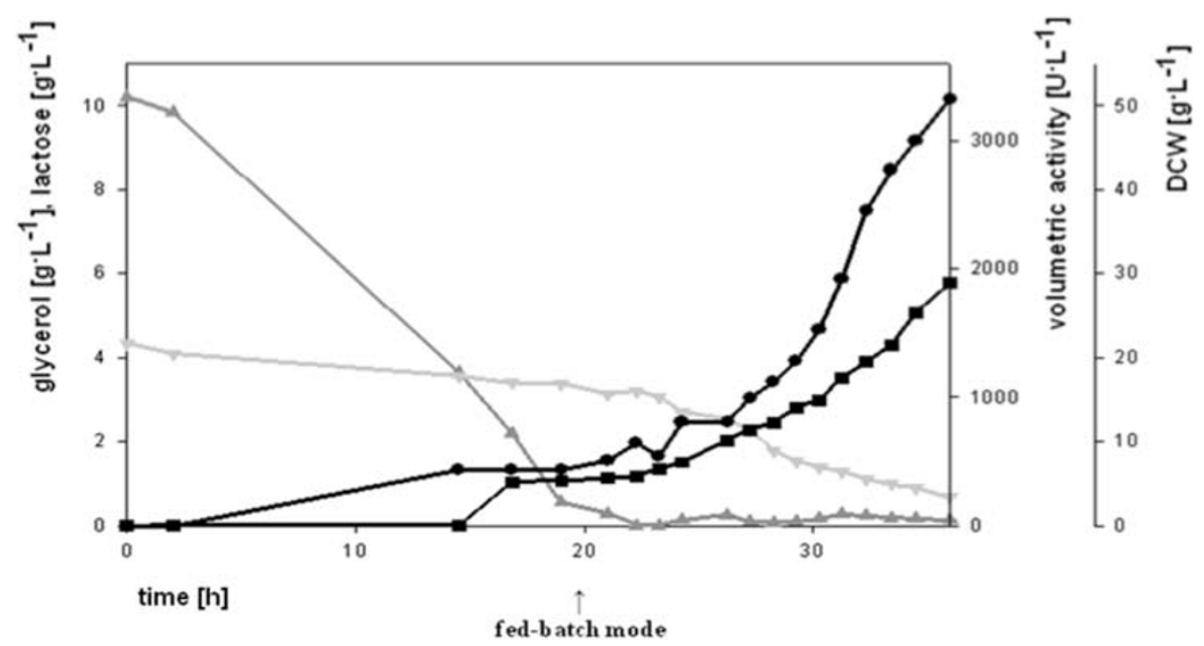

Figure 7 Fed-batch fermentation at $25^{\circ} \mathrm{C}$ with the pCOLD III/POx expression system. (Dark grey triangle), glycerol; (Dark grey triangle), lactose; (Black square), dry cell weight; (Black circle), volumetric activity of POx.

chose $25^{\circ} \mathrm{C}$ as process temperature for the fed-batch fermentation because experiments in batch mode had shown that at this temperature the process time was reasonable compared to the yield of active POx. Results and important parameters of the performed high cell density cultivation using the pCOLD system in a fedbatch mode are shown in Table 3 and Fig. 7. Feeding was initiated $20 \mathrm{~h}$ after inoculation and maintained for $16 \mathrm{~h}$, resulting in a total process time of $36 \mathrm{~h}$. During fed-batch mode the culture grew with a controlled specific growth rate of $\mu=0.15 \mathrm{~h}^{-1}$, which resulted in a reasonable short process time and low IB formation. At the end of the batch phase activity reached $440 \mathrm{U} / \mathrm{L}$, but when feeding was initiated and growth was resumed, activity levels increased exponentially with biomass. Within $16 \mathrm{~h}$ of feeding, POx activity rose to $3300 \mathrm{U} / \mathrm{L}$, which was 10 times the amount of active and soluble enzyme compared to the batch experiments performed at $25^{\circ} \mathrm{C}$. This result underlines the strictly growth associated production of POx. Compared to the amount of soluble, active enzyme, the overall process time was kept significantly short. The highest POx activity in batch experiments using the PCOLD system was $580 \mathrm{U} /$ $\mathrm{L}$ after $49 \mathrm{~h}$ of cultivation. Here, more than 5.5 times the amount of active enzyme was produced within only $36 \mathrm{~h}$ of fermentation.

\section{Conclusions}

In this study we investigated the heterologous expression of the fungal enzyme POx in the prokaryotic host $E$. coli using the T7 RNA polymerase promoter-based pET21d ${ }^{+}$, the L-arabinose inducible pBAD and the pCOLD expression system. In preliminary experiments in baffled flasks at $25^{\circ} \mathrm{C}$ and optimal induction, the pBAD system turned out to be not competitive, the productivity rate of active POx was 5- and 2.3- fold lower than in the other two systems. In subsequent studies with the pET21d $\mathrm{d}^{+}$and the pCOLD system using different conditions for batch fermentations, we optimized the fermentative production of $\mathrm{POx}$ at the bioreactor level by minimizing the formation of inactive inclusion bodies. The temperature of growth was the determining factor for the production of active $\mathrm{POx}$ in E. coli. A growth rate in the range of $0.02-0.20$ $\mathrm{h}^{-1}$ was favorable for the expression of active POx. A process temperature of $25^{\circ} \mathrm{C}$ turned out to be optimal for the large scale production of recombinant, active POx using both expression systems, $\mathrm{pET} 21 \mathrm{~d}^{+}$and $\mathrm{pCOLD}$, regarding productivity $[\mathrm{U} / \mathrm{L} \cdot \mathrm{h}]$ and process time. Finally, to increase the amount of actively expressed POx, we applied a fedbatch strategy to the pCOLD system at $25^{\circ} \mathrm{C}$ with a growth rate of $0.15 \mathrm{~h}^{-1}$. Using this system we achieved the highest productivity rate of active POx with $206 \mathrm{U} /$ L.h, which was 10 -fold higher than the values achieved in batch fermentations. Thus, the fed-batch strategy can be regarded superior to the simple batch mode of fermentation when it comes to produce high levels of active POx within short process times.

\section{Acknowledgements}

The study was supported by the Austrian Science Fund (Fonds zur Förderung der wissenschaftlichen Forschung, Translational Projects L213-B11 and $\mathrm{L} 210-\mathrm{B} 11$ to $\mathrm{DH}$ and $\mathrm{CKP}$, respectively) and the Forschungsförderungsgesellschaft FFG (K+ Programme).

\section{Author details}

${ }^{1}$ Food Biotechnology Lab, Department of Food Sciences and Technology, BOKU - University of Natural Resources and Applied Life Sciences Vienna, Austria. ${ }^{2}$ Research Centre Applied Biocatalysis, Graz, Austria. ${ }^{3}$ School of Biotechnology, Royal Institute of Technology, Stockholm, Sweden. ${ }^{4}$ Department of Nanobiotechnology, BOKU - University of Natural Resources and Applied Life Sciences Vienna, Austria. 


\section{Authors' contributions}

OS and RL designed the experiments, OS and GP performed the cultivations and analyzed data, OS drafted the manuscript, DH and CKP conceived of the study, supervised research and wrote the paper. All authors read and approved the final manuscript

\section{Competing interests}

The authors declare that they have no competing interests.

Received: 9 December 2009

Accepted: 9 March 2010 Published: 9 March 2010

\section{References}

1. Kirk O, Borchert TV, Fuglsang CC: Industrial enzyme applications. Curr Opin Biotechnol 2002, 13:345-351.

2. Marston FAO: The purification of eucaryotic polypeptides synthesized in Escherichia coli. Biochem J 1986, 240:1-12.

3. Hockney RC: Recent developments in heterologous protein production in Escherichia coli. Trends Biotechnol 1994, 12:456-463.

4. Makrides SC: Strategies for achieving high-level expression of genes in Escherichia coli. Microbiol Rev 1996, 60:512-538.

5. Hannig G, Makrides SC: Strategies for optimizing heterologous protein expression in Escherichia coli. Trends Biotechnol 1998, 16:54-60.

6. Baneyx F: Recombinant protein expression in E. coli. Curr Opin Biotechnnol 1999, 10:411-421.

7. Jana S, Deb JK: Strategies for efficient production of heterologous proteins in Escherichia coli. Appl Microbiol Biotechnol 2005, 67:289-298.

8. Schein $\mathrm{CH}$, Noteborn MHM: Formation of soluble recombinant proteins in Escherichia coli is favored by lower growth temperatures. Bio/Technol 1988, 6:291-294.

9. Strandberg L, Enfors SO: Factors influencing inclusion body formation in the production of a fused protein in E. coli. Appl Environ Microbiol 1991, 57:1669-1674.

10. Kim SS, Kim EK, Rhee JS: Effects of growth rate on the production of Pseudomonas fluorescens lipase during the fed-batch cultivation of $E$. coli. Biotechnol 1996, 12:718-722.

11. Vasina JA, Baneyx F: Expression of aggregation-prone recombinant proteins at low temperatures: a comparative study of the Escherichia coli csp A and tac promoter systems. Protein Expr Purif 1997, 9:211-218.

12. Sriubolmas N, Panbangred W, Sriurairatana S, Meevootisom V: Localisation and characterization of inclusion bodies in recombinant $E$. coli cells overproducing penicillin G acylase. Appl Microbiol Biotechnol 1997, 47:373-378.

13. Roessner CA, Devagupta R, Hasan M, Williams HJ, Scott Al: Purification of an indole alkaloid biosynthetic enzyme, strictosidine synthase, from a recombinant strain of Escherichia coli. Protein Expr Purif 1992, 3:295-300.

14. Lilie H, Schwarz E, Rudolph R: Advances in refolding of proteins produced in E. coli. Curr Opin Biotechnol 1998, 9:497-501.

15. Volc J, Denisova NP, Nerud F, Musílek V: Glucose-2-oxidase activity in mycelial cultures of basidiomycetes. Folia Microbiol 1985, 30:141-147.

16. Daniel G, Volc J, Kubátová E: Pyranose oxidase, a major source of $\mathrm{H}_{2} \mathrm{O}_{2}$ during wood degradation by Phanerochaete chrysosporium. Appl Environ Microbiol 1994, 60:2524-2532

17. Leitner $C$, Haltrich D, Nidetzky B, Prillinger $H$, Kulbe KD: Production of a novel pyranose 2-oxidase by basidiomycete Trametes multicolor. Appl Biochem Biotechnol 1998, 70-72:237-248.

18. Haltrich D, Leitner C, Neuhauser W, Nidetzky B, Kulbe KD, Volc J: A convenient enzymatic procedure for the production of aldose-free Dtagatose. Annual New York Academy of Science 1998, 864:295-299.

19. Giffhorn F: Fungal pyranose oxidases: occurence, properties and biotechnological applications in carbohydrate chemistry. Appl Microbiol Biotechnol 2000, 54:727-740.

20. Tasca F, Timur S, Ludwig R, Haltrich D, Volc J, Antiochia R, Gorton L: Amperometric biosensors for detection of sugars based on the electrical wiring of different pyranose oxidases and pyranose dehydrogenases with osmium redox polymer on graphite electrodes. Electroanalysis 2007, 19:294-302.

21. Večerek B, Marešová H, Kočanová M, Kyslík P: Molecular cloning and expression of the pyranose 2-oxidase CDNA from Trametes ochracea MB49 in Escherichia coli. Appl Genet Mol Biotechnol 2004, 64:525-530.
22. Kotik M, Kocanová M, Maresová H, Kyslík P: High-level expression of a fungal pyranose oxidase in high cell-density fed-batch cultivations of Escherichia coli using lactose as inducer. Protein Expr Purif 2004, 36:61-69.

23. Marešová $H$, Večerek B, Hradská M, Libessart N, Bečka S, Saniez MH, Kyslík P. Expression of the pyranose 2-oxidase from Trametes pubescens in Escherichia coli and characterization of the recombinant enzyme. J Biotechnol 2005, 120:387-395.

24. Studier FW, Moffatt BA: Use of bacteriophage T7 RNA polymerase to direct selective high-level expression of cloned genes. J Mol Biol 1986, 189:113-130

25. Guzman LM, Belin D, Carson MJ, Bekwith J: Tight regulation, modulation, and high-level expression by vectors containing the arabinose PBAD promoter. J Bacteriol 1995, 177:4121-4130.

26. Lu C, Bentley WE, Rao G: A high-throughput approach to promoter study using green fluorescent protein. Biotechnol Prog 2004, 20:1634-1640.

27. Vasina JA, Baneyx F: Expression of aggregation-prone recombinant proteins at low temperatures: a comparative study of the Escherichia coli csp A and tac promoter systems. Protein Expr Purif 1997, 9:211-218.

28. Quing G, Ma LC, Khorchid A, Swapna GV, Mal TK, Takayama MM, Xia B, Phadtare S, Ke H, Acton T, Montelione GT, Ikura M, Inouye M: Cold-shock induced high-yield protein production in Escherichia coli. Nat Biotechnol 2004, 22:877-882.

29. Kujawa M, Ebner H, Leitner C, Hallberg BM, Prongjit M, Sucharitakul J, Ludwig R, Rudsander U, Peterbauer C, Chaiyen P, Haltrich D, Divne C: Structural basis for substrate binding and regioselective oxidation of monosaccharides at C3 by pyranose 2-oxidase. J Biol Chem 2006, 281:35104-35115.

30. Danneel HJ, Rössner E, Zeeck A, Giffhorn F: Purification and characterization of a pyranose oxidase from the basidiomycete Peniophora gigantean and chemical analysis of its reaction products. Europ J Biochem 1993, 214:795-802.

31. Bradford MM: A rapid and sensitive method for the quantitation of microgram quantities of protein utilizing the principle of protein-dye binding. Anal Biochem 1976, 72:248-254.

32. Laemmli UK: Cleavage of structural proteins during the assembly of the head of bacteriophage T4. Nature 1970, 227:680-685.

33. Ramirez OT, Zamora R, Espinosa G, Merino E, Bolivar F, Quintero R: Kinetic study of penicillin acylase production by recombinant $E$. coli in batch cultures. Process Biochem 1994, 29:197-206.

34. Mayer MR, Dailey TA, Baucom CM, Supernak JL, MGrady MC, Hawk HE, Dailey HA: Expression of human proteins at the Southeast Collaboratory for Structural Genomics. J Struct Funct Genomics 2004, 5:159-165.

doi:10.1186/1475-2859-9-14

Cite this article as: Spadiut et al:: Evaluation of different expression systems for the heterologous expression of pyranose 2-oxidase from Trametes multicolor in E. coli. Microbial Cell Factories 2010 9:14.

\section{Submit your next manuscript to BioMed Central and take full advantage of:}

- Convenient online submission

- Thorough peer review

- No space constraints or color figure charges

- Immediate publication on acceptance

- Inclusion in PubMed, CAS, Scopus and Google Scholar

- Research which is freely available for redistribution
Biomed Central 